on the history of essential professional societies and associations focus on Lviv institutions. This approach makes it impossible to clarify the regional specifics of Ukrainian economic life and create a panoramic study of the socio-economic movement in the harmonious unity of all its organisational components. As a first step towards overcoming this problem, we are reconstructing the regional policy of the "Zorya" Association of Ruthenian Craftsmen and Industrialists and investigating the activities of its provincial branches.

The purpose of the article is to clarify the features of the regional policy of the "Zorya" Association of Ruthenian Craftsmen and Industrialists.

Results. The research has revealed that "Zorya's" creators already planned to spread their organisational experience to the Galician province. The evidence has been found in the charter of "Zorya" that paid attention to the formation and operation of branches. The oldest Ukrainian craftsmen society established on the charter of Lviv's "Zorya" and connected with it organizationally became "Garazd" in Yavoriv. This association of Ukrainian artisans of the city and its environs was founded in 1887 and functioned until the Second World War. Then "Zorya" branches were established in Przemyrbl, Stryj, Drohobych, Zhovkva and Stanislaviv. Members of these centres have launched active cultural and educational work in cities and counties. The process of establishing new branches of "Zorya" was intensive in the interwar period as well. The society branches appeared in Zhydachiv, Sambir, Ternopil, Boryslav, Pidberetsy, Yaroslavl, Rohatyn, Truskavets and other cities of Galicia. "Zorya" established libraries in their communities, took care of artisan youth, published their magazines, and so on. Such activism transformed "Zorya's" regional offices into the centres of Ukrainian life in the province.

Conclusion. The study has revealed good organisation and considerable success of "Zorya's" regional policy. As of 1939, about 30 branches of the company united more than 1,500 people. Their members carried out a variety of activities, which united previously disparate forces. Through joint cultural work favouring Galician Ukrainians, "Zorya" significantly contributed to the strengthening of national life in towns and villages, previously almost entirely dominated by Polish and Jewish cultural influences.

Keywords: "Zorya", Galicia, regional policy, branch, cultural and educational activities

Одержано редакцією 07.04.2021

Прийнято до публікації 29.06.2021

УДК 94 (477) (092)

DOI: 10.31651/2076-5908-2021-1-65-71

\author{
ZHURAVLOV Sviatoslav, \\ PhD (History), Junior researcher at \\ the Department of source studies of \\ Modern History of Ukraine, \\ Mykhailo Hrushevsky Institute of \\ Ukrainian Archeography and Source \\ Studies of the National Academy of \\ Sciences of Ukraine \\ Orcid ID: 0000-0001-7875-4038 \\ e-mail: zuravlovsvatoslav27@gmail.com
}

\title{
CULTURAL AND PUBLIC ACTIVITY OF MARIA HRUSHEVSKA (VOYAKOVSKA) IN THE LATE NINETEENTH - EARLY TWENTIETH CENTURY
}

The aim of the article is to comprehensively study the cultural and social work of Maria Hrushevska in the late nineteenth - early twentieth century. Summarising our observations on the cultural, educational and social activities of M. Hrushevska during the late nineteenth - early twentieth century, we would like to single out a few points. Firstly, the scholar demonstrated initiative and purposefulness manifested in steady personal growth, regardless of the unfavourable life circumstances. Secondly, Maria Silvestrivna demonstrated a diversity of intellectual interests and proved herself as a translator, cultural and public life organiser, and as a talented teacher. Thirdly, the sacrifice of Maria Hrushevska, her understanding of the need to fully support her husband Mykhailo Hrushevsky in his service to Ukrainians enabled the success of various national projects of the Great Ukrainian.

Key words: M. Hrushevska, cultural and public work, translation activity, Ukrainian societies. 
Formulation of the problem. The research of the role and place of the Hrushevsky family in the cultural and social life of Ukraine in the second half of the XIX - early XX centuries cannot be comprehensive without acknowledging the personality of Mykhailo Serhiyovych's wife Maria Sylvestrivna Voyakovska. According to many contemporaries, she was «Hrushevska in spirit». M. Hrushevska was a friend, assistant, colleague of a prominent Ukrainian scientist and activist, as well as an educator, mentor and advisor for their daughter. Moreover, she was also an original creator. Her activity left a deep mark in the history of Ukrainian culture as Maria Hrushevska was a cultural and educational activist, translator, publicist, pedagogue, art critic, linguistorthographer, critic, literary critic, and folklorist.

Despite such a variety of creative talents of M. Hrushevska, she is still perceived mainly in the «shadow» of her famous husband, making it difficult to reconstruct the «female» side of Ukrainian intellectual history of the modern era. Therefore, we consider the reconstruction of the cultural and public work of Maria Hrushevska (Voyakovska) to be an urgent task. We consider it expedient to start researching this problem from the end of the XIX - the beginning of the XX century, the period of Hrushevska's development as a public intellectual and public activist.

Analysis of sources and recent research. The source basis of our research consists of a variety of personal and creative sources. The most informative materials were the epistolary documents, diaries and memoirs. They also include M. Hrushevska's creative works: her popularscientific articles, translations, public journalism. The article also refers to the most valuable special historiographical studies by R. Dzuban [1] and I. Matiash [2]. Numerous biographical essays dedicated to Mykhailo Hrushevsky reveal many interesting facts about Maria Hrushevska as well [3].

The aim of the article is to comprehensively analyse the cultural and social work of Maria Hrushevska in the late nineteenth - early twentieth century.

The presentation of the main material. The beginnings of M. Voyakovska's cultural and public activity date back to 1893 when she came to Lviv and began teaching at the Queen Jadwiga school (1893-1896). The big city opened an opportunity for the young teacher to join the national and cultural life of Ukrainian Piedmont's capital at that time. There Maria met many famous Galician cultural activists and scholars [3, 72]. Maria Silvestrivna's presence among Ukrainian elite representatives (F. Vovk, V. Doroshenko, M. Kotsyubynsky, M. Mochulsky, I. Franko, and others) influenced her formation as a conscious Ukrainian. Their community was a special scientific and cultural centre where activists discussed literature and art, news of public life and the problems of Ukrainians. That environment formed M. Hrushevska's outlook, helper forge her the character and highlighted her purposefulness, consistency and persistence.

In Lviv, Maria Voyakovska also met her future husband Mykhailo Hrushevsky. They got married on May 23, 1896, in the village Skala in the Ternopil region [4, 421]. However, opposing the social practices of that time, M. Hrushevska, after becoming the wife of a professor at Lviv University, did not stop her active cultural and educational work. On the contrary, having received support from her loved one, she became, as we have already noted, «Hrushevska by spirit», i.e., a conscious activist for Ukrainian culture.

Literary translations were an important area of Maria Hrushevska's activity during the Lviv period. She was fluent in several foreign languages and translated works by English, German, Russian, Norwegian and French writers. The activist was one of the first to realize the importance of translating the best examples of world literature as a powerful spiritual enrichment source of the Ukrainian people, their culture and literature.

Maria Hrushevska dedicated most of her attention to French prose: from classical literature to scientific works related to culturological problems and history of Ukraine. Maria Silvestrivna was a translator of individual French authors and an initiator of their translations, engaging likeminded writers in this noble cause. Samples of M. Hrushevska's translation heritage can be found in «Literary-Scientific Herald» pages for 1898-1903, along with translations made by Panteleimon Kulish, Ivan Franko, and other outstanding writers. Among her most important translations into Ukrainian there are works by Emile Zola («Salva the Criminal», «Frog»), Francois Coppйе («At the Table», «Time to Sleep»), Alphonse Dode («In a New Apartment», «Memories of the Chief of Staff»), Guy de Maupassant («Eagle», «Spring Evening», «First Snow», «Farmer»), Vladimir Mikulich (the story «Mimochka engaged»), Anton Chekhov (stories «Men», 
«Confusion», «A Slander»). M. Hrushevska also translated works by Franz Poppe, Ivan Turgenev, Arthur Schnitzler and others. She also published her translation of a collection of short stories by Anton Chekhov «A Nightmare» (1901).

The textual structure of Maria Hrushevska's translations is rather peculiar: she always accompanied her translations with prefaces where she provided brief information about the author and substantiated the importance of the selected texts for the Ukrainian reader. M. Hrushevska also changed the numbering of sections and gave them different titles if necessary. Furthemore, Maria Silvestrivna sometimes provided accurate information about the edition of the writer's work used for translation.

M. Hrushevska translated the works of Emil Zola the most. Such preference stems from the aesthetic tastes of Maria Silvestrivna herself. The scale of Zola's thinking, the society-centred content, the realistic orientation of his works, the desire to evaluate the phenomenon of art in the light of philosophical, political, moral problems of today, make Zola's literary works close to journalism genre. Alphonso Dode was another favourite author of M. Hrushevska. After translating "In the New Apartment» and «Memory of the Chief of Cabinet», M. Hrushevska noted two defining features of his creative style: the first one being humour, irony and brightness of imagination; the second one - naturalistic accuracy of observations, parallel realism.

At the end of the XIX century, Maria Silvestrivna became interested in the work of Guy de Maupassant. Her translations of short stories «Eagle», «Spring Evening», «First Snow», «Farmer» are marked by neo-romanticism that was so popular in Europe at that time: the celebration of the ability to do a feat, spiritual nobility, fullness of life, exaltation of passion. M. Hrushevska's translations of A. Chekhov's stories («Men», «Confusion», «Obmova») that depicted the life of the Russian countryside are also accompanied by certain parallels with the Ukrainian countryside.

We would like to note that Maria Silvestrivna's work was an example of women's social self-realization at that time. At the end of the XIX century, Ukrainian society maintained a clear division of gender roles between men and women and did not allow new gender relations to develop freely. The «New Woman», on the one hand, tried to live and create according to men's standards, but on the other, she declared her independence and wanted to go beyond the traditional canon. As for Maria Hrushevska, the most radical changes in her views on the relationship between a man and a woman and on her own life appeared under the influence of the translation of Volodymyr Mikulich's novel «Mimochka engaged». From that point, she decided not only to support her husband in the family but to assist him in scientific, cultural and educational activities.

At the end of the XIX century, a few women in Western Ukraine understood the historical inevitability and necessity of an organized women's movement $[5,123]$. Unlike most passive compatriots, Maria Hrushevska, who was active and enterprising by spirit, directed her energy and talent to the new social movement. In 1894 she became a member of the "Women's Committee» headed by N.I. Kobrynska. The purpose of this society was the development of the women's movement in Western Ukraine. The members of the committee actively promoted the women's rights issue through lectures and relevant publications in the Ukrainian language that clarified the current situation of Ukrainian citizens and the struggle of women. Secondly, they raised the awareness of Ukrainian women and engaged them in a movement similar to the movement of women in other developed countries. Relying on the support of her husband M. Hrushevsky, I. Franko, N. Kobrynska, Maria Silvestrivna devoted a lot of time to correspondence, organization of various congresses, meetings, establishing connections with the Dnipro activists $[6,146]$ who supported broad involvement of women in social work and cultural life.

In addition, participating in the work of the women's committee, M. Hrushevska helped raise funds for the purchase of a house for Ivan Franko. For this purpose, Maria Silvestrivna personally made effort to intensify the activity of a large number of Galician communities, which allowed to raise the necessary funds.

Having lived in Lviv since 1893, Maria Hrushevska was actively involved not only in the women's movement but also in the social life of Western Ukraine in its various manifestations. She was a participant in various public events of many Ukrainian cultural and educational societies such as the Shevchenko Scientific Society, the Academic Society «Bonfire», «People's House», «Prosvita» $[7,122]$. 
Let us dwell in more detail on the participation of M. Hrushevska in the activities of the academic society «Bonfire» that consisted primarily of students. Its goal was to unite Ukrainians in the struggle for their rights. The society was also a centre of scientific and social life, and it provided moral and material assistance to its members. Another project of the society was helping the sick. In particular, Maria Silvestrivna actively involved Ukrainians in Lviv in the «Bonfire» activity. Moreover, she organised the printing of literary and scientific works. The publishing business was established through the organisation of scientific readings, evening theatrical performances, scientific and educational trips and lectures for a wide range of society members. Those events usually involved both young people and famous scientists.

The famous Ukrainian actress Solomiya Krushelnytska had a significant influence on the formation of Maria Hrushevska's outlook during this period. She was incredibly talented and very popular, she toured all over Galicia and in many European countries. However, Solomiya Krushelnytska was, first of all, an outstanding Ukrainian woman who had the faith in a happy great Ukraine and tried to inspire other Ukrainians. In her correspondence with Maria Voyakovska, she strongly supported and encouraged her public activities. In her letter dated September 1, 1894, Solomiya Krushelnytska wrote to Maria Silvestrivna: «You probably think that I have already forgotten about you, or maybe you do not want to think about me. I have not forgotten about You and I will never do, because it seems to me that You should be loved for Your work and for Your good heart» $[8,99]$.

Thus, having been supported in her cultural and public work by many prominent compatriots, primarily by her husband, Maria Hrushevska immersed herself in the work of various cultural and educational organizations. She dedicated her time to the Lviv society «Narodny Dim» («People's House»). «People's Houses» are institutions with libraries and reading rooms, amateur art groups, and sometimes brass bands. In the late nineteenth - early twentieth century «People's Houses») were the centres of nurturing the national identity of Ukrainian culture and they were usually financed by public money.

In 1896 M. Hrushevska became a member of the «Rus Pedagogical Society» that aimed at creating public, secondary and higher schools, supporting public and home education based on the native language; providing moral and material assistance to members of the society; actively fighting for the national character of the school. Members of the society gathered at conferences and pedagogical meetings, helped solve urgent issues in schools, and published a pedagogical magazine for Ukrainian schoolchildren. In 1912, the Russian Pedagogical Society was renamed into the Ukrainian Pedagogical Society.

M. Hrushevska was an intellectual, and she considered gaining new knowledge an essential component of life and leisure. In particular, for a long time (since 1906) she deepened her education as a student of the «Osnova» («Foundation») at Lviv Polytechnic. Founded in 1897 as a scientific society, «Osnova» contributed to the development of the scientific interests of its members. The manifesto of the society stated its aim was «to be the centre of scientific and social life of Ukrainian students of Lviv Polytechnic» [9]. According to the specialization of the polytechnic departments, «Osnova» had six scientific subdivisions (sections). M. Hrushevska was a student of the art section that united students of architecture and drawing department.

M. Hrushevska also took part in the work of SSS where her husband was the chairman since 1897. She became a member of the society in 1899. Maria Silvestrivna initiated and took part in establishing of a museum, library and archive of SSS. Furthermore, she organised the collection of Ukrainian antiquities, translated for the «Literary-Scientific Herald» and translated plays for Ukrainian theatre. Maria Zankovetska, a close friend of M. Hrushevska, asked her to prepare for publication numerous serial and monographic editions. They included series of works by I. Franko, V. Hnatiuk, O. Konysky that were first published in the collections of SSS. M. Hrushevska also worked on many studies about members of the society who have made a significant contribution to the development of Ukrainian historical science, language, literature, ethnography and folklore, geography, anthropology and other disciplines.

Maria Silvestrivna's work in «Literary-Scientific Herald» was important as well. The peculiarities of publishing the journal in Lviv and Kyiv allowed uniting Ukrainians divided by the Austro-Hungarian and Russian empires to discuss forbidden national problems. The journal 
analysed the problems of both Western Ukraine and the national liberation movement in the Dnipro region in a particular column «From Ukrainian life». One of the most active contributors to this column was M. Hrushevska. In the context of the general attention of SSS to bibliography and bibliographic works, M. Hrushevska actively cooperated with the review department of the «Notes of SSS». In their pages, she gave many critical reviews of contemporary novelties of fiction, proving herself a connoisseur of the psychology of literary creativity [10].

Maria Hrushevska took an active part in her husband's other cultural and publishing projects. In December 1898 she became a member of the Ukrainian-Rus Publishing Union (URVS). The idea of creating such a publishing structure that would support Ukrainian writers was nurtured by M. Hrushevsky. However, it is essential to emphasize that the activities of the URVS were not limited to promoting the creative realization of individual artists. The union's aim was to unite the efforts of authors from all over Ukraine with different political views and literary orientations; bring Ukrainian book publishing out of the narrow framework and systematize the themes of works, in particular, by preparing and printing them in series. Having worked in the URVS, Maria Silvestrivna together with her husband focused their efforts on solving specific tasks: to promote cultural development and intensification of the literary process; to support (through one-time assistance and royalties) Ukrainian writers; to produce the best original and translated samples of fiction and scientific works; to certify the existence of a nationally oriented creative generation capable of self-organization; to promote the development of the Ukrainian literary language.

In the early 1900's M. Hrushevska participated in the activities of numerous cultural and educational organizations, notably the «Club of Ruthenians». First of all, the members of this club considered it necessary to spread the rights to the Ukrainian language in higher educational institutions - Lviv and Chernivtsi universities; they also organised demonstrations for the rights of Galician «Ruthenians» within Austria-Hungary.

From 1903 M. Hrushevska joined the work of the women's union «Trud» («Labour») whose task was to equip tailoring workshops and training in tailoring. She also supported the college under the tutelage of «Labour». This direction of work in society, in turn, encouraged women to realize their ideas, which they sought to implement, as well as helping many disadvantaged to find shelter, to master a new profession.

Participating in public societies «Rus Zakhoronka», «Medical Care», I.P. Kotlyarevsky Ukrainian-Rus Drama Society, Maria Hrushevska together with like-minded people, contributed to solving many cultural, educational and social problems. At the same time, these societies created an appropriate socio-cultural environment that influenced the intellectual and creative evolution of members of the Hrushevsky family.

The year 1905 became quite fruitful for M. Hrushevska. At that time Maria and Mykhailo Hrushevsky worked hard on reforming the «Literary-Scientific Herald», which at the end of 1905 was transferred to the «Ukrainian-Rus Publishing Union». The journal began to perform somewhat different tasks and focused more on reflecting socio-political problems in the context of the unification of Ukrainians on different sides of Zbruch [11, 38]. From January 1907, the magazine began to be published in Kyiv, which led to a partial change in its editorial board, including Maria Silvestrivna. Since then, she has been very active in helping her husband with the affairs of the «Literary-Scientific Herald» [12].

After the Russian Empire's revolutionary events in 1905, the Hrushevsky family increasingly visited Kyiv, where M. Hrushevsky tried to develop Ukrainian cultural life. The events of that time were also reflected in the diary of Maria Silvestrivna. At that time the Hrushevsky family was especially close to Yevhen Chykalenko, Volodymyr Antonovych and Mykola Lysenko. The relationship, which began as a business one, later grew into a long-term friendship between families. From Maria Silvestrivna's diary entries, we also see that respect and trust, mutual understanding and sincerity always prevailed among the Hrushevsky family members. In her diary, she also mentioned the rich cultural life of her family.

From 1904 M. Hrushevska began active work in the Society of Admirers of Ukrainian Literature, Science and Art which was founded in 1904 on the initiative of Mykhailo Hrushevsky and Ivan Trush for the «development of Rus art». The chairman of the Society was Mykhailo Hrushevsky, and Maria Hrushevska, together with secretaries Ivan Trush and Mykhailo Mochulsky. 
The work of the secretaries was to compose the most practical manifesto of the Society, which would allow uniting around itself even more supporters. Another task was to establish an effective structure of the Society. One of the important activities of the Society was the organization of university lectures, Ukrainian studies courses following the model of «free university».

In 1912, M. Hrushevska took an active part in the charity «Lviv Book Society» activities. Her direct work in this society was to provide material assistance, organize the publishing of brochures, books needed by the Ukrainian community, and involve authors, scholars, and literary critics.

Conclusions. Summarizing our observations on the cultural, educational and social activities of M. Hrushevska during the late nineteenth - early twentieth century, we would like to single out a few points. Firstly, the scholar demonstrated initiative and purposefulness, manifested in steady personal growth, regardless of the unfavourable life circumstances. As a result, the Ukrainian activist received a brilliant education and gained considerable practical experience in cultural and social work. Secondly, Maria Silvestrivna demonstrated a diversity of intellectual interests and proved herself as a translator, cultural and public life organiser, and as a talented teacher. Therefore, she soon became a prominent figure in the domestic women's movement and opened up its new perspectives. Thirdly, the sacrifice of Maria Hrushevska, her understanding of the need to fully support her husband Mykhailo Hrushevsky in his service to Ukrainians enabled the success of various national projects of the Great Ukrainian. Finally, assisting Mykhailo Hrushevsky in implementing his numerous cultural, scientific and public initiatives on both sides of Zbruch, M. Hrushevska made a significant contribution to the cultural unity of Ukrainians on the eve of the difficult trials for our people with the First World War among them.

\section{Список використаної літератури}

1. Дзюбан Р. В. Село Підгайчики - батьківщина Марії Грушевської / Р. В. Дзюбан // Пам’ятки України: історія та культура. -2001. - Ч. 1 - 2. - С. 58 - 65.

2. Матяш І. Б. Катерина Грушевська: Життя і діяльність [Текст] / І. Б. Матяш. - К.: Україна, 2004. $-240 \mathrm{c}$.

3. Пиріг Р. Я., Тельвак В. В. Михайло Грушевський: біографічний нарис / Р. Я. Пиріг, В. В. Тельвак. - К.: Либідь, 2016. - 576 с.

4. Дзюбан Р. В. Як одружувався Михайло Грушевський / Р. В. Дзюбан // Український історик. 2002. - Ч. 1-4. - C. $416-422$.

5. Кость С. І. Жіноча преса / С. І. Кость // Вісник Львівського національного університету : сер.: Журналістика. - 2007. - Вип. 30. - С. 123 - 141.

6. Смоляр Л. І. Минуле заради майбутнього. Жіночій рух Наддніпрянської України II пол. XIX поч. XX ст. Сторінки історії / Л. І. Смоляр. - Одеса: Астропринт. - 408 с.

7. Дзюбан Р. В. Львівські адреси Михайла Грушевського / Р. В. Дзюбан // Пам'ятки України: історія та культура. - 2005. - Ч. 1. - С. $122-131$.

8. Горинь В. І. Невідомі листи С. Крушельницької до М. Грушевської / В. І. Горинь // Дзвін. 1993. - № 1. - С. $97-102$.

9. Кобринець Н. Б. Бібліотека студентського товариства «Основа»: становлення та основні етапи діяльності / Н. Б. Кобринець // Вісник Львівського університету. Сер.: Книгознавство, бібліотекознавство та інформаційні технології. - 2006. - Вип. 1. - С. 181-195.

10. Майхер В.А., Купчинський О.А. Наукове товариство імені Т. Шевченка у Львові / В. А. Майхер, О. А. Купчинський. - Львів: б. в., 2003. - 739 с.

11. Конта Р. М. Реформування «Літературно-наукового вісника» та проблема висвітлення етнографічних досліджень у Науковому товаристві ім. Т. Г. Шевченка / Р. Конта // Вісник Книжкової палати. - 2013. - № 10. - С. 36 - 38.

12. Листи Марії Грушевської до Володимира Дорошенка (1942 - 1943 рр.) / Вступ, публікація та коментарі М. Вальо // Записки Львівської наукової бібліотеки ім. В. Стефаника. - Львів, 2004. - Вип. 12. - С. $464-494$.

\section{References}

1. Dziuban, R. V. (2001). The village of Pidhaichyky is the birthplace of Maria Hrushevska. Sights of Ukraine: history and culture, $1-2,58-65$. (in Ukr.)

2. Matiash, I. B. (2004). Kateryna Hrushevska: Life and activity. K.: Ukraina. (in Ukr.)

3. Pyrih, R. Ya., Telvak,V. V. (2016). Mykhailo Hrushevsky: biographical essay. K.: Lybid. (in Ukr.)

4. Dziuban, R. V. (2002). How Mykhailo Hrushevsky got married. Ukrainian historian, 1- 4, 416 422. (in $\mathrm{Ukr}$.) 
5. Kost', S. I. (2007). Women's Press. Visnyk of Lviv National University: series: Journalism, 30, 123 - 141. (in Ukr.)

6. Smoliar, L. I. (1998). Women's movement of Dnieper Ukraine II floor. XIX-beg. XX century Pages of history. Odesa: Astroprynt. (in Ukr.)

7. Dziuban, R. V. (2005). Lviv addresses of Mykhailo Hrushevsky. Sights of Ukraine: history and culture, 1,122 - 131. (in Ukr.)

8. Horyn', V. I. (1993). Unknown letters of S. Krushelnytska to M. Hrushevska. The bell, 1, 97 - 102. (in Ukr.)

9. Kobrynets, N. B. (2006). Library of the student society «Osnova»: formation and main stages of activity. Visnyk of Lviv National University. Ser: Bibliography, library science and information technology, 1, 181-195. (in Ukr.)

10. Maikher, V. A., Kupchynskyi, O. A. (2003). Taras Shevchenko Scientific Society in Lviv. Lviv. (in Ukr.)

11. Konta, R. M. (2013). Reforming the «Literary-Scientific Bulletin» and the problem of coverage of ethnographic research in the Scientific Society. Taras Shevchenko. Bulletin of the Book Chamber, 10,36 - 38. (in Ukr.)

12. Val'o, M. (2004). Letters of Maria Hrushevska to Volodymyr Doroshenko (1942 - 1943). Notes of the Lviv Scientific Library named after V. Stefanika, 12, 464 - 494. (in Ukr.)

ЖУРАВЛЬОВ Святослав Андрійович, кандидат історичних наук, молодший науковий співробітник відділу джерелознавства нової історії України Інститут української археографії та джерелознавства імені М. Грушевського НАН України,

e-mail: zuravlovsvatoslav27@gmail.com

\section{КУЛЬТУРНО-ГРОМАДСЬКА ДІЯЛЬНІСТЬ МАРІЇ ГРУШЕВСЬКОЇ (ВОЯКОВСЬКОЇ) НАПРИКІНЦІ ХІХ - НА ПОЧАТКУ ХХ ст.}

Постановка проблеми. Досліджуючи роль $і$ місце родини Грушевських у культурногромадському житті України в другій половині XIX - на початку XX ст., особливу увагу варто приділити особі дружині Михайла Сергійовича Марії Сильвестрівні Вояковській. Вона, за спостереженням багатьох сучасників, була «Грушевською духом». М. Грушевська була не лише другом, помічником, соратником визначного українського вченого і громадського діяча, не тільки вихователем, наставником і порадником для їхньої дочки, а й самобутньою творчою постаттю. В історії української культури вона залишила глибокий слід як культурно-просвітницька діячка, перекладач, публіиист, педагог, мистеитвознавеиь, мовознавеиь-орфограф, критик, літературознавець, фольклорист.

Мета статті полягає у всебічному дослідженні культурно-громадської праці Марії Грушевської наприкінці ХIX - на початку XX століття.

Наукова новизна статті полягає у спробі комплексного аналізу інтелектуальної біографії Марії Грушевської до початку Першої світової війни.

Висновки. Підсумовуючи намі спостереження над культурно-освітньою та громадською діяльністю М. Грушевської протягом кіния XIX- початку XX ст., звернемо увагу на декілька моментів. По-перше, у вічі впадає ініціативність і цұілеспрямованість інтелектуалки, щчо проявлялося в неухильному особистісному зростанні, незважсаючи на більш ніж неприхильні жстттєві обставини. В підсумку, украӥнська діячка отримала блискучу освіту $i$ здобула чималий практичний досвід культурно-громадської праиі. По-друге, вкажемо на різноплановість інтелектуальних інтересів Марії Сильвестрівни, що потужно проявила себе $і$ як перекладачка, $і$ як організатор культурногромадського життя, i як талановитий педагог. Цим вона у короткому часі стала помітною діячкою вітчизняного жіночого руху, котра відкривала його нові перспективи. По-третє, у вічі впадає жертовність Марії Грушевської, розуміння нею потреби всебічно підтримати свого чоловіка Михайла Грушевського у його служінні украйнству, що уможливило успіх більшості національних проектів Великого Украӥния. Врешті, сприяючи Михайлу Сергійовичу в реалізачії його численних культурно-наукових і громадських ініціатив по обидва боки Збруча, М. Грушевська зробила значний внесок у справу культурної соборності украӥнства напередодні важких випробувань для нашого народу, якими виявилася Перша світова війна.

Ключові слова: М. Грушевська, культурно-громадська прачя, перекладацька діяльність, украӥнські товариства. 